\title{
PERTUMBUHAN DAN BIOLOGI REPRODUKSI UDANG GALAH (Macrobrachium rosenbergii) DI SUNGAI LEMPUING SUMATERA SELATAN
}

\author{
Agus Djoko Utomo*)
}

\begin{abstract}
ABSTRAK
Sungai Lempuing sebagian besar merupakan daerah rawa banjiran, habitat yang baik untuk kehidupan beberapa jenis ikan dan udang. Penelitian bertujuan untuk mendapatkan informasi tentang pertumbuhan dan musim pemijahan udang galah ( $M$. rosenbergii) di Sungai Lempuing. Penelitian pendugaan pertumbuhan udang galah dengan cara penandaan memberikan hasil bahwa untuk udang jantan konstanta kecepatan pertumbuhan $(K)=0,012$, panjang maksimum $\left(L_{\infty}\right)=29,6 \mathrm{~cm}$ dan berat maksimum $\left(W_{\infty}\right)=240 \mathrm{~g}$. Sedangkan untuk udang betina $(K)=0,013, L_{\infty}=27,7 \mathrm{~cm}$ dan $W_{\infty}=160 \mathrm{~g}$. Penghitungan jumlah telur udang galah dengan kisaran ukuran $16-22 \mathrm{~cm}$ dengan menggunakan metoda gravimetri menunjukkan bahwa fekunditasnya berkisar antara $40.185-107.690$ butir telur. Pemeriksaan gonad secara rutin berdasarkan Nikolsky menunjukkan bahwa musim pemijahan terjadi pada musim penghujan (Desember-Maret) yang ditandai oleh TKG pada stadium IV dan banyak telur sudah dibuahi. Sungai Lempuing merupakan tempat pembesaran, pematangan gonad, dan pemijahan bagi udang galah
\end{abstract}

\section{ABSTRACT: Growth and biological reproduction of Giant Prawn (Macrobrachium rosenbergii) at Lempuing River South Sumatera. By : Agus Djoko Utomo}

\begin{abstract}
Flood plain ecosystem of Lempuing River is suitable habitat for fish and prawn. The objectives of this research are to get information about growth and spawning season of giant prawn (M. rosenbergii) at Lumpuing river. Growth estimation of giant prawn by using tagging method showed that growth parameter of male giant prawn $(K)=0.012$, length infinity $\left(L_{\alpha}\right)=29.6 \mathrm{~cm}$ and weight infinity $\left(W_{\infty \alpha}\right)=240$ $g$ respectively. While for the female $K=0,013, L_{\infty} 27,7 \mathrm{~cm}$ and $W_{\infty}=160 \mathrm{~g}$ respectively. Fecundity estimation by using gravimetric method showed that fecundity on total length between $16-22 \mathrm{~cm}$ were 40,185-107,690 eggs. Estimation on the spawning season of giant prawn by sampling the gonad at time series, revealed that a peak spawning season which is indicated by stage $\mathrm{N}$ of the gonad and berried eggs were found during a rainy season (December-March). The study found that Lempuing River was a suitable area for growth, gonad maturity, and spawning of giant prawn.
\end{abstract}

\section{KEYWORDS : $\quad$ growth, tagging experiment, reproduction, giant prawn}

\section{PENDAHULUAN}

Sungai Lempuing merupakan salah satu anak Sungai Komering di Sumatera Selatan, yang sebagian besar badan airnya merupakan rawa banjiran (flood plain). Habitat seperti tersebut cocok untuk pemijahan beberapa jenis ikan, selain itu juga merupakan daerah penangkapan bagi nelayan (Welcomme, 1979). Udang galah merupakan jenis udang air tawar yang berukuran besar. Udang dewasa banyak dijumpai di perairan sungai rawa banjiran.

Ciri khusus udang galah yaitu : bentuk rostrum yang panjang seperti pedang, bagian atas mempunyai 11-13 gerigi sedangkan pada bagian pasang kaki jalan (periopoda), bagian badan (abdomen) terdiri dari lima ruas masing masing dilengkapi dengan kaki renang (pleiopoda) (Hadie dan Hadie, 1993; Djajadireja et al., 1980). Di antara kaki renang udang galah betina agak melebar membentuk ruangan untuk mengerami telur (broodchamber). Pada udang galah jantan dewasa, sepasang kaki jalan ke dua ukurannya lebih panjang dan besar bila dibanding dengan kaki yang lain, bisa mencapai 1,5 kali panjang badannnya. Sedangkan pada yang betina perbedaan ukuran kaki tersebut tidak mencolok (Ling, 1969 dalam Hadie dan Hadie, 1993).

Udang galah dapat memijah sepanjang tahun dan puncaknya pada musim penghujan (Desember-Februari). Pemijahan berlangsung di perairan tawar yang jauh dari kuala. Induk udang yang membawa telur yang sudah dibuahi akan beruaya ke hilir sungai mencari air yang mengandung kadar garam tertentu untuk melakukan penetasan telur (Djajadireja et al.,

\footnotetext{
Peneliti pada Balai Riset Perikanan Perairan Umum
} 
lambat dari pada pertumbuhan panjang (kurus). Pada gambar 3 juga terlihat bahwa udang galah betina pertumbuhannya lebih lambat dari pada yang jantan, hal ini disebabkan udang betina banyak memerlukan energi untuk mematangkan gonad. Induk betina sebelum melakukan pemijahan biasanya mangalami ganti kulit (moulting), selama proses postmoulting memerlukan energi untuk keseimbangan tekanan osmotik, energi diambil bukan dari pakan melainkan dari perombakan protein dalam tubuh, selama fase pergantian kulit ini udang galah betina tidak makan sampai kulit baru mengeras. Namun fase pergantian kulit ini sangat diperlukan karena kulit udang yang keras akan membatasi pertumbuhan (Ling dalam Hadie dan Hadie, 1993).

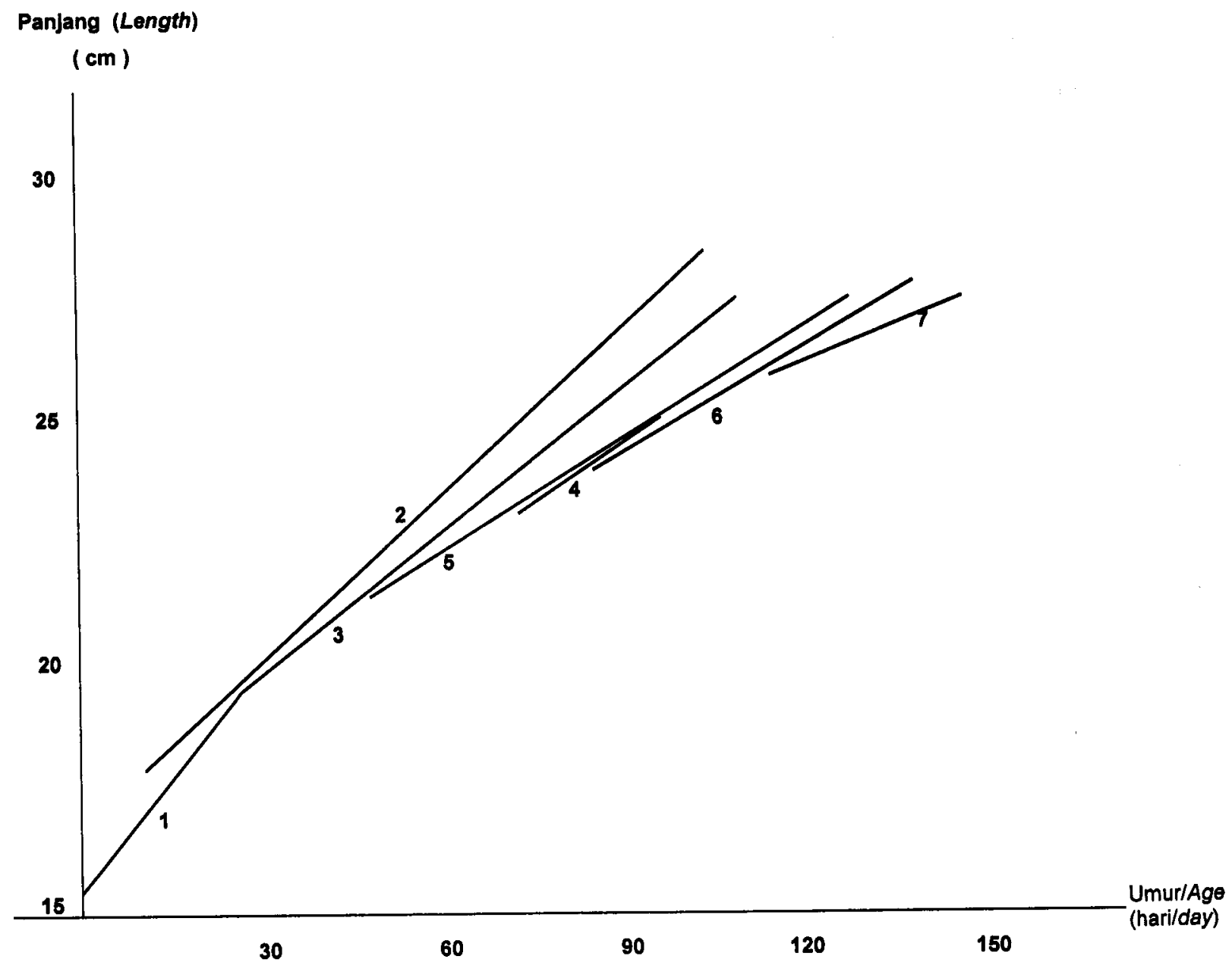

Keterangan (Remarks) : 1,2,3,4,5,6,7 adalah udang dengan nomor tanda $: 1=P 0007 ; 2=P 0034 ; 3=P 007 ; 4=P 0621 ; 5=P 0303$; $6=\mathrm{P} 0155 ; 7=\mathrm{P} 0404$

Gambar 2. Pertambahan panjang udang galah jantan bertanda sejak dilepas sampai tertangkap kembali di Sungai Lempuing

Figure 2. Length increment of male giant prawn tagged from releasing to recapture at Lempuing River

Pertumbuhan udang galah pada saat dewasa lebih lambat dari pada pertumbuhan saat umur muda, hal tersebut disebabkan karena saat dewasa banyak energi yang dipakai untuk pemeliharaan organ tubuh yang sudah melemah atau rusak dan untuk produksi organ seksual. Transfer energi dalam tubuh organisme diutamakan untuk keperluan metabolisma, pergerakan, pemeliharaan organ tubuh, reproduksi, dan sisanya untuk pertumbuhan (Effendie, 1997). 
Tabel 1. Pertambahan panjang udang galah betina bertanda sejak dilepas sampai tertangkap kembali di Sungai Lempuing

Table 1. Length increment of female giant prawn tagged from releasing to recapture at Lempuing River

\begin{tabular}{ccccccc}
\hline No. tagging & $\begin{array}{c}\mathbf{L 1} \\
(\mathbf{m m})\end{array}$ & $\begin{array}{c}\mathbf{L 2} \\
\mathbf{( m m})\end{array}$ & $\begin{array}{c}\Delta \mathbf{L} \\
(\mathbf{m m})\end{array}$ & $\begin{array}{c}\Delta \mathbf{T} \\
\text { hari (day) }\end{array}$ & $\begin{array}{c}\mathbf{L} \mathbf{m}^{\prime} \\
(\mathbf{m m})\end{array}$ & $\Delta \mathbf{L} / \Delta \mathbf{T}$ \\
\hline P0626 & 188 & 198 & 10 & 9 & 193 & 1,11 \\
P0628 & 188 & 200 & 12 & 11 & 194 & 1,09 \\
P0015 & 185 & 220 & 35 & 35 & 202 & 1,00 \\
P0039 & 200 & 212 & 12 & 17 & 206 & 0,70 \\
P0152 & 225 & 240 & 15 & 25 & 232 & 0,60 \\
\hline
\end{tabular}

Tabel 2. Pertambahan panjang udang galah jantan bertanda sejak dilepas sampai tertangkap kembali di Sungai Lempuing

Table 2. Length increment of male Giant Prawn tagged from recapture to releasing at Lempuing River

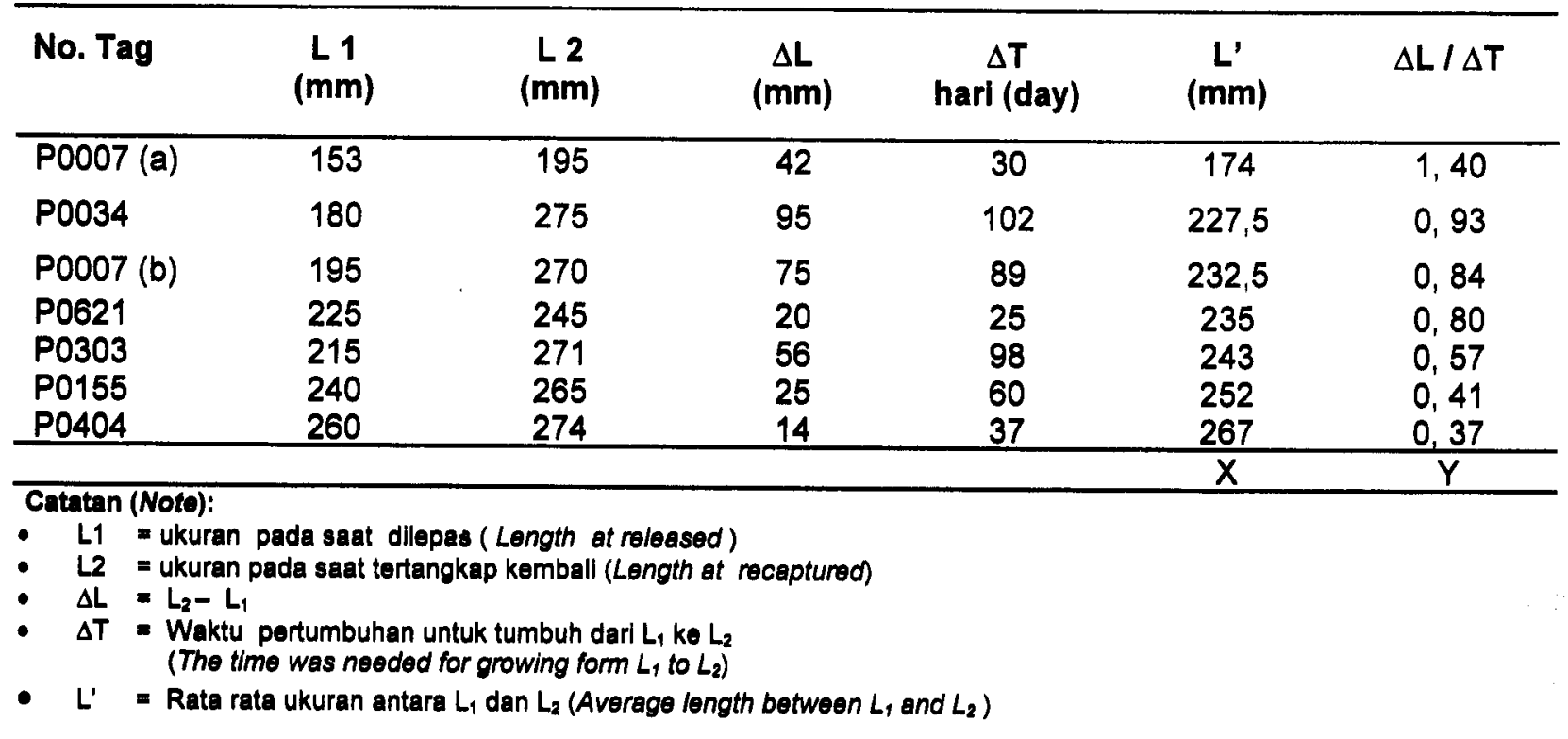

\section{Blologi Reproduks|}

\section{(1). Porkembangan Tingkat Kematangan Gonad}

Berdasarkan data kematangan gonad udang pada bulan Juli 2000 hingga bulan Maret 2001 (Gambar 4) dapat disimpulkan bahwa ada perkembangan tingkat kematangan dari bulan Juli (musim kemarau) dan seterusnya hingga bulan Maret (musim penghujan). Pada musim kemarau (Juli-November) tingkat kematangan gonad didominansi oleh tingkat I sampai dengan tingkat III, sedangkan pada saat musim penghujan (Desember-Mei) didominansi oleh tingkat III sampai tingkat IV, bahkan pada bulan Februari dan Maret sudah banyak induk udang yang telah dibuahi (kawin).

Berdasarkan informasi tersebut dapat disimpulkan bahwa Sungai Lempuing merupakan tempat yang baik bagi pematangan gonad dan pemijahan induk udang galah. Hal tersebut disebabkan bahwa di daerah rawa banjiran banyak tersedia pakan (energi) yang cukup, berupa detritus untuk pematangan gonad. Pada waktu musim penghujan banyak tersedia air tawar sampai meluap ke daerah hutan di tepian sungai, habitat tersebut sangat disenangi untuk pemijahan udang galah dan organisme air lainnya (Welcomme, 1979). 


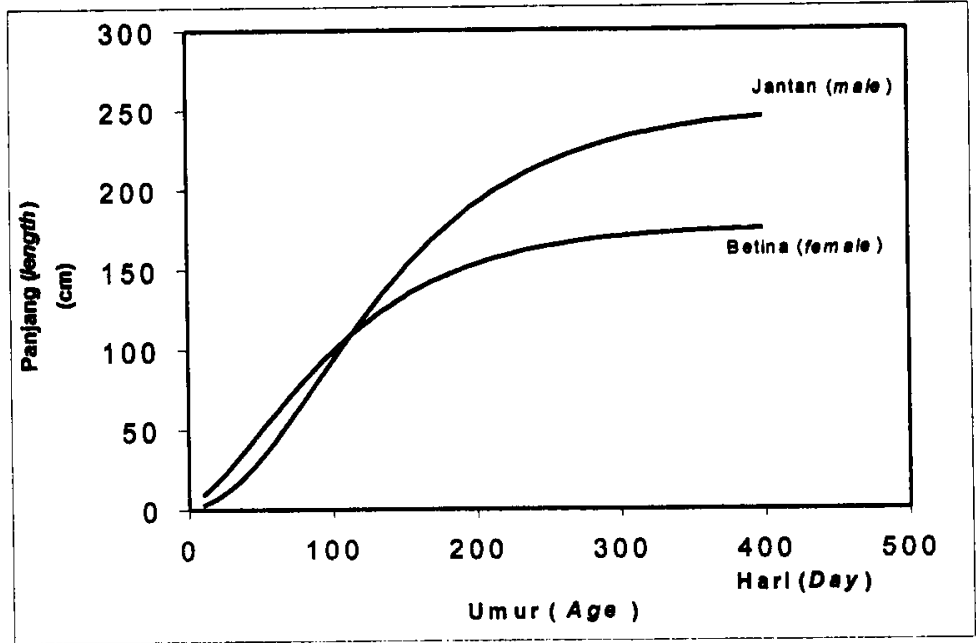

A. Pertumbuhan Panjang / Length of Growth

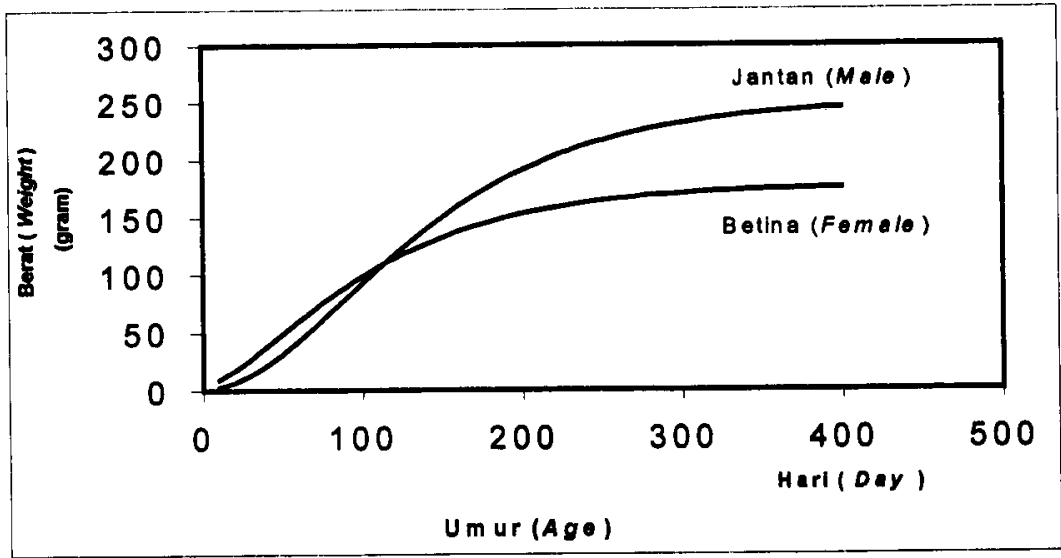

B. Pertumbuhan Berat / Weight of Growth

Gambar 3. Simulasi pertumbuhan udang galah di Sungai Lempuing Figure 3. Growth simulation of giant prawn at Lempuing River

Udang galah yang mengandung telur yang sudah dibuahi pada bulan November 2000 ada satu ekor $(2,3 \%)$ gonad yang sudah dibuahi, gonad berwarna kuning jingga. Pada bulan Februari 2001 terdapat delapan ekor (18,6\%) induk yang mengandung telur sudah dibuahi dan gonad yang berwarna kuning ada satu ekor, jingga tiga ekor, dan coklat empat ekor. Pada bulan Maret 2001 terdapat 18 ekor $(37,5 \%)$ induk udang mengandung telur yang sudah dibuahi, gonad tersebut berwarna kuning dua ekor, jingga sembilan ekor, coklat lima ekor dan abu-abu dua ekor.

Warna pada gonad yang sudah dibuahi menunjukkan tingkat perkembangan. Warna kuning menunjukkan bahwa udang tersebut baru melakukan pemijahan, kemudian berkembang menjadi jingga, seterusnya coklat dan abu abu. Warna abu abu yang merupakan indikasi sudah siap untuk menetas hanya dijumpai pada bulan Maret, apabila tidak segera menemukan air asin maka telur tersebut akan mati atau menetas namun larvanya tidak bertahan lama. Sehingga segala sesuatu (alat tangkap, bendungan) yang menghambat ruaya udang akan menggagalkan penetasan udang galah.

\section{Fekunditas}

Jumlah telur sangat tergantung dengan ukuran udang, makin besar ukuran cenderung makin banyak jumlah telurnya. Udang yang berukuran 16$22 \mathrm{~cm}$, jumlah telurnya antara 40.000 sampai dengan 108.000 butir (Tabel 3). Diameter telur berkaitan dengan tingkat kematangan gonad, telur yang lebih matang akan mempunyai diameter yang lebih besar. Sebagai contoh udang yang baru dibuahi telurnya berwarna kuning, frekuensi terbanyak pada diameter $0,40 \mathrm{~mm}$ sampai dengan $0,50 \mathrm{~mm}$. Sedangkan telur yang lebih matang berwarna coklat, frekuensi terbanyak pada diameter $0,6 \mathrm{~mm}$. 


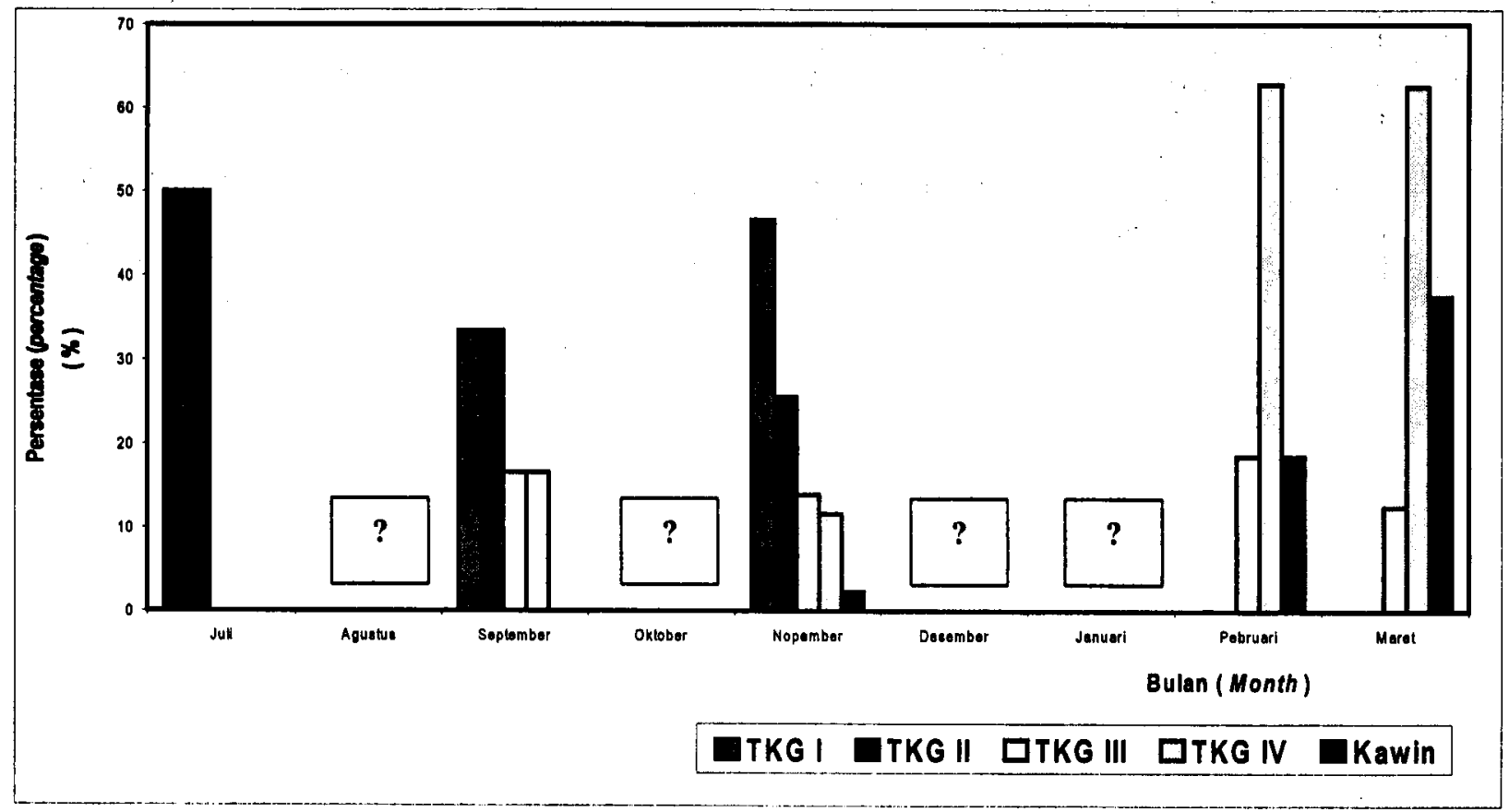

Catatan (Note):

TKG = Tingkat kematangan gonad (gonad maturity stage)

(?) = Tidak dilakukan pengambilan contoh (No sampling)

Gambar 4. Tingkat kematangan gonad udang Galah di Sungai Lempuing (\%)

Figure 4. Gonad maturity stage of Giant Prawn at Lempuing River (\%)

\section{KESIMPULAN DAN SARAN}

\section{Kesimpulan}

1. Udang galah di Sungai Lempuing dapat tumbuh dengan baik. Pertumbuhan udang jantan lebih cepat daripada udang betina.

2. Musim kematangan gonad dan pemijahan udang galah di Sungai Lempuing terjadi pada saat musim penghujan.

3. Sungai Lempuing merupakan tempat yang cocok bagi udang galah untuk tumbuh, pematangan gonad, dan pemijahan.

\section{Saran}

Perlu adanya upaya pembenihan udang galah secara in-situ, karena di Sungai Lempuing masih sering dijumpai induk yang matang kelamin dan induk yang sudah dibuahi. Selanjutnya hasil pembenihan tersebut ditebar ke perairan umum guna rehabilitasi populasi.

\section{DAFTAR PUSTAKA}

Djajadireja, $R_{i}$ H. Hadidjaya, dan A. Ismail 1980. Pembenihan Udang Galah (M. rosenbergin) Skala Kecil. Lembaga Penelitian Perikanan Darat Bogor. 43 pp

Effendie, M.I. 1997. Biologi Perikanan. Yayasan Pustaka Nusantama. $155 \mathrm{pp}$.

Hadie, W dan L.E Hadie 1993. Pembenihan Udang Galah. Kanasius, Yogyakarta. 110 pp.

Hoggarth, D 1994. Survey Methodology. Marine Resources Assessment Group (MRAG), London. $50 \mathrm{p}$.

Mantel, L.H 1983. The Biology of Crustacea, Internal Anatomy and Physiological Regulation. Academic Press, New York and London. 5: 1261.

Pauly, D .1984. Some Simple Methods for the Assessment of Tropical Fish Stock. FAO, Rome, 234: $52 \mathrm{pp}$. 
Samuel, S. Adjie, dan A.D Utomo 1991. Aspek Biologi Udang Galah (M.rosenbergii) di Sungai Lempuing Sumatera Selatan. Bulletin Penelitian Perikanan Darat Bogor. 10 (2) : 32-39.

Sparre, P and S.C Venema 1992. Introduction to Tropical Fish Stock Assessment. DANIDA- FAO. Rome, Italy, 306 (1): 376 pp.
Utomo, A.D 1997. Perikanan Udang Galah (M.rosenbergii) di Sungai Lempuing Sumsel (unpublished).Loka Penelitian Perikanan Air Tawar Palembang. 16 pp.

Utomo, A.D., Z. Nasution, dan Samuel. 1991. Kegiatan Penangkapan Udang Galah ( $M$. rosenbergii ) di Sungai Lempuing Sumatera Selatan. Bulletin Penelitian. Perikanan Darat Bogor, 10 (3): 15-21. 
Lampiran 1. Pengumpulan data udang galah bertanda yang tertangkap kembali di Sungai Lempuing Appendix 1. Collecting tags data of recaptured Giant Prawn at Lempuing River

Barang siapa menangkap udang bertanda di Sungai Lempuing harap mencatat beberapa keterangan yang diperlukan yaitu:

\begin{tabular}{|l|l|l|}
\hline Nomor : & Tanggal : & Panjang (cm) \\
& & \\
\hline
\end{tabular}

\begin{tabular}{|l|l|l|}
\hline Alat tangkap : & Nama : & Alamat : \\
Lokasi : & & \\
& & \\
\hline
\end{tabular}

Lepaskan nomor yang melekat pada badan udang, kemudian nomor beserta catatan tersebut kirim ke stasiun penelitian Lubuk Lampam, atau mengirim langsung ke kantor Balai Riset Perikanan Perairan Umum Palembang PO BOX 1125.

Setiap penyerahan satu nomor yang disertai dengan catatan yang lengkap akan diberi baju kaos. Apa bila dapat menyerahkan beserta udangnya masih hidup dan nomor masih melekat di badan, maka akan diberi hadiah tambahan sebesar dua kali lipat harga udang.

Pada akhir tahun seluruh nomor yang didapatkan akan diundi, yang dapat memenangkan akan mendapatkan hadiah TV berwarna. 
Agus Djoko Utomo

Lampiran 2. Posisi pemasangan tanda pada udang galah (M. rosenbergii) Appendix 2. Tag Position of Giant Prawn (M. rosenbergii)

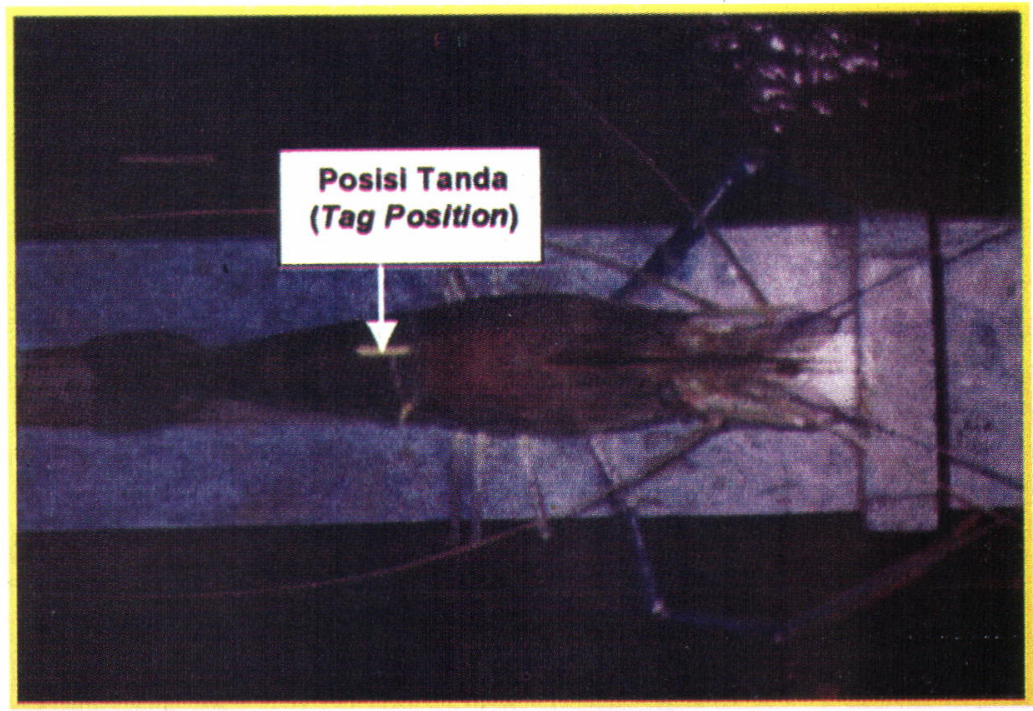

